\title{
High accumulation of PCDD, PCDF, and PCB congeners in marine mammals from Brazil: A serious PCB problem
}

\author{
Paulo R. Dorneles ${ }^{\mathrm{a}, *}$, Paloma Sanz ${ }^{\mathrm{b}}$, Gauthier Eppe ${ }^{\mathrm{c}}$, Alexandre F. Azevedo ${ }^{\mathrm{h}}$, Carolina P. Bertozzi ${ }^{\mathrm{d}}$, \\ María A. Martínez ${ }^{\mathrm{b}}$, Eduardo R. Secchi ${ }^{\mathrm{e}}$, Lupércio A. Barbosa ${ }^{\mathrm{f}}$, Marta Cremer ${ }^{\mathrm{g}}$, Mariana B. Alonso ${ }^{\mathrm{a}, \mathrm{h}}$, \\ João P.M. Torres ${ }^{\mathrm{a}}$, José Lailson-Brito ${ }^{\mathrm{h}}$, Olaf Malm ${ }^{\mathrm{a}}$, Ethel Eljarrat ${ }^{\mathrm{i}}$, Damià Barceló ${ }^{\mathrm{i}, \mathrm{j}}$, Krishna Das ${ }^{\mathrm{k}}$ \\ ${ }^{a}$ Biophysics Institute, Federal University of Rio de Janeiro (UFRJ), Brazil \\ b Persistent Organic Pollutant Group, Environment Department, CIEMAT, Madrid, Spain \\ c Centre for Analytical Research and Technology, Mass Spectrometry Laboratory, Liege University, Belgium \\ ' Projeto Biopesca, Praia Grande, SP, Brazil

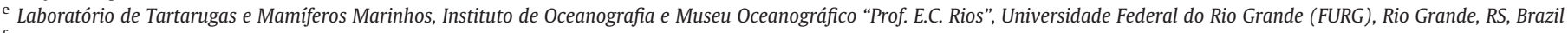 \\ ${ }^{\mathrm{f}}$ Instituto ORCA, Vila Velha, ES, Brazil \\ g Universidade da Região de Joinville, Departamento de Ciências Biológicas, Laboratório de Nectologia, São Francisco do Sul, SC, Brazil \\ ${ }^{\text {h }}$ Aquatic Mammal and Bioindicator Laboratory (MAQUA), School of Oceanography, Rio de Janeiro State University (UERJ), Brazil \\ ${ }^{i}$ Department of Environmental Chemistry, IDAEA, CSIC, Barcelona, Spain \\ j Catalan Institute for Water Research (ICRA), Parc Científic i Tecnològic de la Universitat de Girona, Girona, Spain \\ ${ }^{\mathrm{k}}$ Laboratory for Oceanology, MARE Center, Liege University, Belgium
}

\section{H I G H L I G H T S}

- Dioxin-like PCBs accounted for over $83 \%$ of the total TEQ for all cetaceans

- Negative correlations were found between length and TEQ values in franciscanas.

- PCB concentrations found are among the highest ever reported for cetaceans.

\section{A R T I C L E I N F O}

\section{Article history:}

Received 9 March 2012

Received in revised form 3 June 2013

Accepted 3 June 2013

Available online $\mathrm{xxxx}$

Editor: Adrian Covaci

\section{Keywords:}

Dioxins

Furans

PCBs

Dolphins

Brazil

\begin{abstract}
A B S T R A C T
Blubber samples from three delphinid species (false killer whale, Guiana and rough-toothed dolphin), as well as liver samples from franciscana dolphins were analyzed for dioxins and related compounds (DRCs). Samples were collected from 35 cetaceans stranded or incidentally captured in a highly industrialized and urbanized area (Southeast and Southern Brazilian regions). Dioxin-like PCBs accounted for over $83 \%$ of the total TEQ for all cetaceans. Non-ortho coplanar PCBs, for franciscanas (82\%), and mono-ortho PCBs (up to $80 \%$ ), for delphinids, constituted the groups of highest contribution to total TEQ. Regarding franciscana dolphins, significant negative correlations were found between total length (TL) and three variables, $\Sigma$ TEQ-DRCs, ¿TEQ-PCDF and ¿TEQ non-ortho PCB. An increasing efficiency of the detoxifying activity with the growth of the animal may be a plausible explanation for these findings. This hypothesis is reinforced by the significant negative correlation found between TL and PCB126/PCB169 concentration ratio. DRC concentrations (ng/g lipids) varied from 36 to 3006, for franciscana dolphins, as well as from 356 to 30,776, for delphinids. The sum of dioxin-like and indicator PCBs varied from 34,662 to 279,407 ng/g lipids, for Guiana dolphins from Rio de Janeiro state, which are among the highest PCB concentrations ever reported for cetaceans. The high concentrations found in our study raise concern not only on the conservation of Brazilian coastal cetaceans, but also on the possibility of human health problem due to consumption of fish from Brazilian estuaries.
\end{abstract}

(c) 2013 Elsevier B.V. All rights reserved.

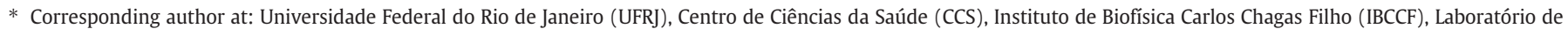

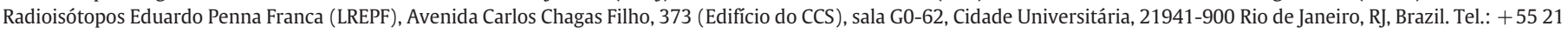
25615339; fax: +552122808193.

E-mail addresses: dorneles@biof.ufrj.br, dornelespr@gmail.com (P.R. Dorneles),g.eppe@ulg.ac.be (G. Eppe), azevedo.alex@uerj.br (A.F. Azevedo), carolinabertozzi@hotmail.com (C.P. Bertozzi), edu.secchi@furg.br (E.R. Secchi), lupercio@orca.org.br (L.A. Barbosa), marta.cremer@univille.br (M. Cremer), alonso.mb@gmail.com (M.B. Alonso), jptorres@biof.ufrj.br (J.P.M. Torres), lailson@uerj.br (J. Lailson-Brito), olaf@biof.ufrj.br (O. Malm), eeeqam@iiqab.csic.es (E. Eljarrat), krishna.das@ulg.ac.be (K. Das).
} 


\section{Introduction}

Special concern has been raised since the 1960s about the environmental persistence, bioaccumulative capacity and toxicity of dioxins and related compounds (DRCs), such as polychlorinated dibenzo-pdioxins (PCDDs), polychlorinated dibenzofurans (PCDFs), as well as non-ortho and mono-ortho polychlorinated biphenyls (dioxin-like PCBs) (Bopp et al., 1991; Cleemann et al., 2000). DRCs constitute a group of polyhalogenated aromatic hydrocarbons that have similarities from the structural, chemical and toxicological point of view (McDonald et al., 1994). These persistent and bioaccumulative contaminants are carcinogenic (Chaloupka et al., 1993; Cleemann et al., 2000), immunosuppressive (Harper et al., 1993), and induce a number of pathological effects related to their endocrine disrupting action in mammals, including reproductive impairment (Schecter et al., 2006). Despite their toxicity, studies on environmental levels of DRCs in Brazil are scarce (de Assunção et al., 2005).

Dioxins are unintentionally-produced contaminants, generated by different processes, including paper bleaching, synthesis of pesticides, herbicides, fungicides and PCBs, as well as burning of wastes and vegetation (Alcock et al., 1999; Cleemann et al., 2000; McDonald et al., 1994; Schecter et al., 2006). Taking the latter activity into consideration, it is interesting to mention that intentional burning of sugar cane crops and forest fires are common in Brazil (Lara et al., 2005; Santilli et al., 2005).

Polychlorinated biphenyls (PCBs) were used in a number of industrial activities, but mainly as dielectric fluids in capacitors and transformers (Alcock et al., 1999). Manufacture, use and commercialization of PCBs have been prohibited in Brazil since the beginning of the 1980s (Azevedo e Silva et al., 2007; Penteado and Vaz, 2001). However, the same restrictive law allows the functioning of already installed apparatuses up to their complete replacement or substitution of their dielectric fluid (Azevedo e Silva et al., 2007; Penteado and Vaz, 2001). Industrial and urban developments, at present, spread along the entire Brazilian coast; however, they are particularly concentrated along the Southeastern and Southern Brazilian regions (Saboia, 2000). Therefore, evaluating environmental contamination by DRCs in these two regions constitutes a matter of interest.

Using samples from cetaceans, the present study constitutes the first scientific investigation on DRC levels in marine biota from Brazil. Due to their high level in the food chain, their long life-span, and, for some species, their year-round presence in polluted and relatively small areas, cetaceans are important indicators of environmental contamination (Bjørge, 2001; O'Shea and Tanabe, 2003). In addition to providing information on the pattern and magnitude of DRCs that are reaching the top positions of the marine food webs in Brazil, analyses of cetacean tissues provide valuable data for conservation purposes. The high marine mammal exposure to DRCs in different regions of the globe raises concern about the conservation of the species, as adverse effects on reproductive and immune systems have been demonstrated for these animals (Dietz et al., 1989; Reijnders, 1986). The Brazilian economic growth and the subsequent use and degradation of the coastal zone are a concern for the conservation of small coastal cetaceans. In the present study, samples from four cetacean species (franciscana dolphin, Pontoporia blainvillei; Guiana dolphin, Sotalia guianensis; rough-toothed dolphin, Steno bredanensis; and false killer whale, Pseudorca crassidens) were analyzed for DRCs.

Franciscana and Guiana dolphins are small cetaceans that can reach up to 1.5 and $2.0 \mathrm{~m}$, respectively. They occur exclusively in western Atlantic coastal waters of South (franciscana and Guiana dolphins) and Central (Guiana dolphins) America (Cunha et al., 2005; Secchi et al., 2003). Due to their nearshore distribution, these dolphin species are especially vulnerable to the effects of human activities. Rough-toothed dolphins and false killer whales occur in tropical to warm temperate waters all over the world (Baird, 2009; Miyazaki and Perrin, 1994). In Brazil, these species occur predominantly on the continental shelf (Bisi, 2011; Dorneles et al., 2010, 2008b, 2007a) and rough-toothed dolphins can even be found in shallow coastal waters (Flores and Ximinez, 1997). Rough-toothed dolphins can occasionally reach more than $2.8 \mathrm{~m}$ of total length (Jefferson, 2009). Taking into consideration that this continental shelf (CS) delphinid has many prey species in common with estuarine dolphin species, such as the Guiana dolphin (Melo et al., 2010, submitted for publication), the greater size of rough-toothed dolphins means that these CS delphinids have anatomical characteristics that enable them to feed on larger fish, and hence, on prey specimens that had a longer exposure time to pollutants than those consumed by Guiana dolphins. Although it is still controversial whether or not false killer whales feed on other cetacean species, they are known to prey on large and long-lived fish such as tunas and swordfish (Baird et al., 2008). This feature, combined with the hypothesis that organohalogen compounds from bays and estuaries of the Southeastern Brazilian region are transported to the adjacent Atlantic Ocean waters (Dorneles et al., 2010), makes DRC determination in rough-toothed dolphins and false killer whales a matter of great scientific interest.

Because of these reasons, cetaceans were used in the present study as indicators of micropollutant trophic flow, as well as sentinel species for human health. The latter approach is based on the fact that many fish species are consumed by humans in Rio de Janeiro at the size preyed on by the delphinid species analyzed in our study (Melo et al., 2010, submitted for publication). In addition, it is also of great interest to investigate if accumulation of persistent bioaccumulative toxicants can pose an additional threat to these cetacean species.

\section{Materials and methods}

\subsection{Sampling and sample preparation}

Liver and blubber samples were obtained by different marine mammal research groups from five Brazilian states (Fig. 1), including the Southeastern [Espírito Santo (ES), Rio de Janeiro (RJ) and São Paulo (SP) states] and the Southern [Santa Catarina (SC) and Rio Grande do Sul (RS) states] regions of the country. They were collected through the necropsy of cetaceans either incidentally captured in fishing operations or stranded on the beaches. Liver samples were collected from franciscana dolphins, comprising fourteen males from Rio Grande do Sul (RS, n = 3), Santa Catarina (SC, n = 2), São Paulo (SP, males, $\mathrm{n}=6$ ) and Espírito Santo (ES, $\mathrm{n}=3$ ) states, as well as six female franciscana dolphins from São Paulo (SP, females, $\mathrm{n}=6$ ) state. Blubber samples were collected in RJ from 15 delphinids, comprising 11 Guiana dolphins (males, $n=7$; females, $n=4$ ), three rough-toothed dolphins (males, $\mathrm{n}=1$; females, $\mathrm{n}=2$ ) and one false killer whale (female, $\mathrm{n}=1$ ). After dissection, samples were wrapped in aluminum foil and kept frozen $\left(-20^{\circ} \mathrm{C}\right)$ until analyses.

\subsection{Analytical procedure-targeted compounds}

The following dioxins and furans were targeted for analysis: 2,3,7,8-Tetra CDD; 1,2,3,7,8-Penta CDD; 1,2,3,4,7,8-Hexa CDD; $1,2,3$, 6,7,8-Hexa CDD; 1,2,3,7,8,9-Hexa CDD; 1,2,3,4,6,7,8-Hepta CDD; Octa CDD (OCDD); 2,3,7,8-Tetra CDF; 1,2,3,7,8-Penta CDF; 2,3,4,7,8Penta CDF; $1,2,3,4,7,8$-Hexa CDF; $1,2,3,6,7,8$-Hexa CDF; $1,2,3,7,8$, 9-Hexa CDF; 2,3,4,6,7,8-Hexa CDF; 1,2,3,4,6,7,8-Hepta CDF; 1,2,3, 4,7,8,9-Hepta CDF; Octa CDF (OCDF). Concerning dioxin-like PCBs, the following congeners (IUPAC numbers) were targeted for analysis: $77 ; 81 ; 126 ; 169 ; 105 ; 114 ; 118 ; 123 ; 156 ; 157 ; 167$ and 189 . Toxic equivalent (TEQ) concentrations of PCDD/Fs and dioxin-like PCBs were calculated using the World Health Organization (WHO)-2005 toxic equivalency factors (TEF) (van den Berg et al., 2006). Concentrations below detection limits were considered as zero (lower bound TEQ). For blubber samples, in addition to all the mentioned above 


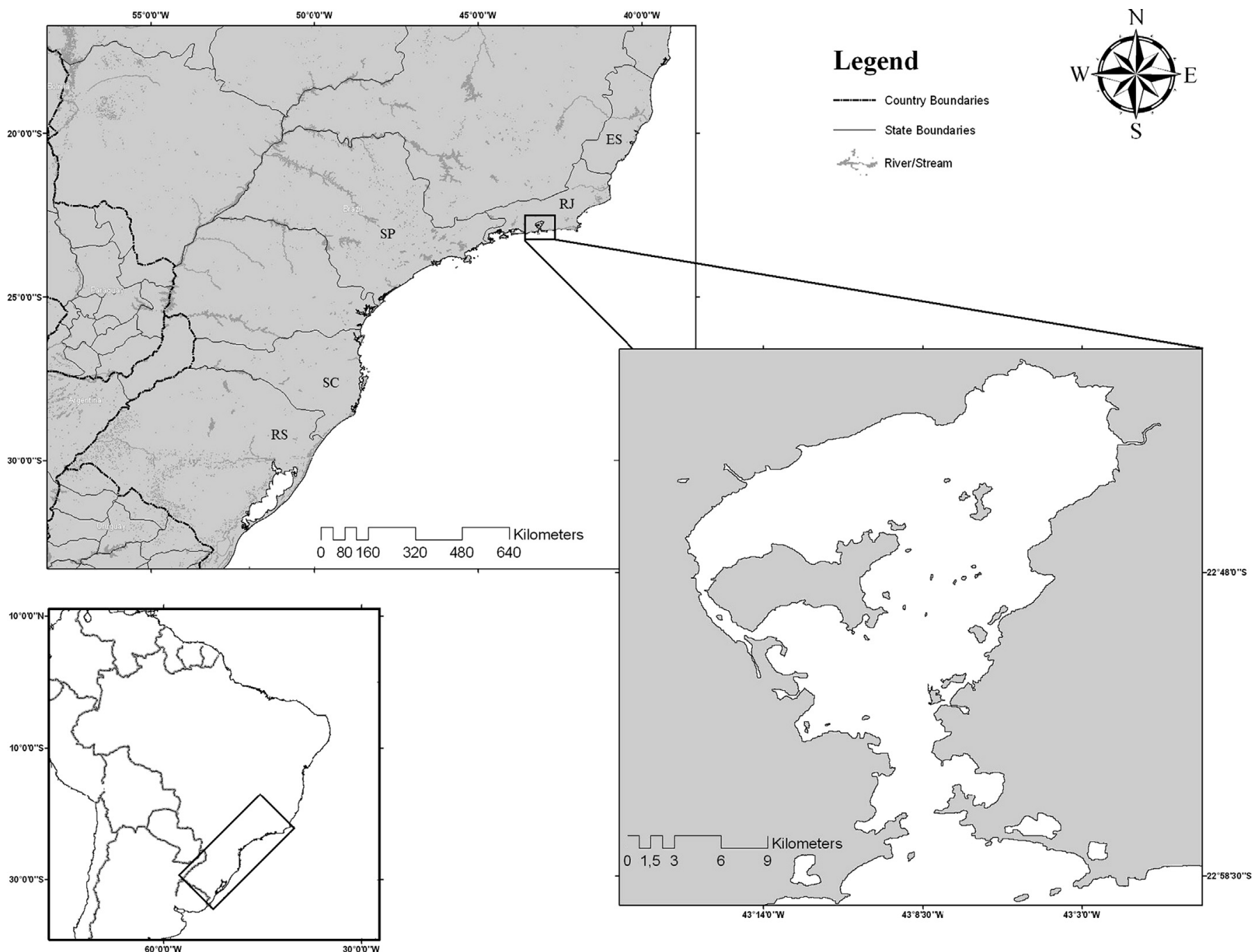

Fig. 1. Brazilian map amplifying Rio Grande do Sul (RS), Santa Catarina (SC), São Paulo (SP), Rio de Janeiro (RJ) and Espirito Santo (ES) states. Guanabara Bay is complementarily amplified.

DRCs, levels of indicator-PCBs (IUPAC numbers: 28, 52, 101, 138, 153, 180) were also measured.

\subsection{Analytical procedure-liver sample analysis}

The analytical procedure has been detailed elsewhere (Eljarrat et al., 2008). Briefly, samples were fortified with ${ }^{13} \mathrm{C}_{12}$-labeled PCDD/F and ${ }^{13} \mathrm{C}_{12}$-labeled PCB quantification standard solutions (Wellington Laboratories Inc., Canada), EPA 1613 LCS and WP-LCS, and extracted using a Dionex ASE100 at the following conditions: hexane, $100{ }^{\circ} \mathrm{C}$, 1500 psi, 90\% flush volume and two static cycles (Focant et al., 2001). After extraction, the solvent was removed and, subsequently fat content was determined gravimetrically. Resulting extracts were transferred into a separation funnel and liquid-extracted with concentrated sulphuric acid to remove organic matter. Clean-up stage was performed in an automated purification Power Prep ${ }^{\mathrm{TM}}$ System (FMS, Inc., USA) including acidic silica gel and basic alumina columns for mono-ortho PCB purification and an additional carbon column for PCDD/F and coplanar PCB cleanup. Different mixtures of hexane:DCM were used to recover mono-ortho PCBs while retaining interfering compounds. PCDD/Fs and coplanar PCBs were recovered with toluene. The final extracts were concentrated avoiding dryness, spiked with EPA1613-ISS and WP-ISS internal standard solutions (Wellington Laboratories Inc., Canada) and further analyzed by GC-HRMS.

\subsection{Analytical procedure-blubber sample analysis}

The extraction, purification and measurement methods are described elsewhere (Focant et al., 2001). Briefly, blubber samples were extracted by pressurized liquid extraction (PLE) using a Dionex (Sunnyvale, CA, USA) ASE 200 extractor. Conditions were: $33 \mathrm{ml}$ extraction cells filled approximately $5 \mathrm{~g}$ of blubber sample and sodium sulphate, $20 \mathrm{ml}$ of hexane per cycle, 5 min cycle time, two cycles per extraction, pressure of 1500 p.s.i. The fat extracts were dried on sodium sulphate prior to complete solvent evaporation. A solution of hexane/dichloromethane was added to aliquots of about 200-300 mg of extracted lipids. The lipid extracts were then spiked with a mixture containing seventeen ${ }^{13} \mathrm{C}$-labeled 2,3,7,8-substituted dioxins isomers, 4 coplanar PCBs isomers (EDF-4144, LGC Promochem) and 8 mono-ortho PCB isomers (Campro Scientific WP-LCS). An automated multi-column clean-up was performed on the Power-Prep system (FMS, Waltham, MA, USA). The lipid content was determined gravimetrically. All analyses were performed by GC-HRMS using a MAT95XL high-resolution mass spectrometer (Finnigan, Bremen, Germany) and a Hewlett-Packard (Palo Alto, CA, USA) 6890 series gas chromatograph.

\subsection{Statistical treatment}

Due to the small sample sizes, non-parametric tests were used for investigating possible correlations between compounds and 
biological parameters (Spearman's correlation test), as well as for investigating possible differences between species, sexes, and regions, regarding pollutant levels and profiles (Mann-Whitney $U$ test). Due to the low number of individuals of some species/groups, only data from franciscana dolphins from SP and Guiana dolphins from RJ were used for statistical evaluation. The Statistica 7.0 Statistical Software System was used for statistical analyses and the level of significance was set at $\mathrm{p} \leq 0.05$.

\section{Results and discussion}

PCDD, PCDF and dioxin-like (non-ortho and mono-ortho) PCB concentrations and TEQ values (pg.g ${ }^{-1}$, l.w.), as well as percentages to $\Sigma T E Q$ in liver or blubber of cetaceans from Southeastern and Southern Brazilian regions, are presented in Table 1.

The use of TEFs to achieve TEQ constitutes an accurate procedure for the assessment of the toxic potential of a complex mixture of pollutants that are capable of triggering Aryl hydrocarbon (Ah) receptormediated effects, such as DRCs (Sanderson and Van Den Berg, 1999). Considering that metabolization of DRCs is also mediated by the Ah receptor, as well as that metabolizing rates for xenobiotics may vary according to age (Reijnders, 2003) and gender (Hall, 2002), possible correlations with the total length and possible sex-related differences were investigated not only for DRC concentrations but also for TEQ values.

\subsection{Franciscana dolphins}

Dioxin-like PCBs accounted for 83-96\% of the total TEQs in the hepatic tissues of franciscana dolphins. In this context, non-ortho coplanar PCBs deserve to be highlighted, since the group contributed to $82 \%$ of the total TEQs, on average. Among the latter group, PCB-126 was by far the congener of greatest importance. In fact, of the measured DRCs, PCB-126 contributed to the majority of the total TEQ in all franciscana dolphins (mean 78\%, SD 11\%). However, PCB-118 occurred in the highest concentrations, which varied from 19.7 to $563.9 \mathrm{ng} / \mathrm{g}$ (l.w.). PCDDs and PCDFs accounted for, on average, 10\% of the total TEQs. The predominant PCDD/F congener found in the livers of franciscana dolphins was OCDD, with concentrations ranging between 32 and $1093 \mathrm{pg} / \mathrm{g}$ (l.w.). Concentrations of PCDDs were greater than those of PCDFs in all individuals. However, regarding the TEQ values (TEQ pg/g l.w.), levels were in general higher for PCDFs. Among furans, 2,3,4,7,8-PeCDF provided the highest contribution to total TEQ.
It is important to keep in mind that while analyzing franciscana dolphins from RS, SC, SP and ES, individuals from three different management areas are being considered. It has been proposed that franciscana should be split into four stocks for management purposes, three of which occur in Brazilian waters (Secchi et al., 2003). Each stock inhabits discrete areas named Franciscana Management Areas (FMA): FMA I, including coastal waters of ES and RJ states; FMA II, covering SP to SC states; and FMA III, comprising the coastal waters of RS state and Uruguay (Secchi et al., 2003). A recent study from our research team (Lailson-Brito et al., 2011) has shown that different ecological franciscana dolphin populations could exhibit remarkably distinct organochlorine compound bioaccumulation profiles, characterized by different $\Sigma \mathrm{DDT} / \Sigma \mathrm{PCB}$ ratios, even within the same management area (FMA II). However, in our study there was no distinction among areas. Instead, there was great variation among individuals (Fig. 2).

According to Ballschmiter and Wittlinger (1991), the environmental levels of many organohalogen compounds in Northern and Southern Hemispheres are a consequence of emissions within each half of the planet independently. As DRCs are pollutants of urban/industrial origin, it is worth mentioning that SP houses a human population of approximately 40 million people (Rudge et al., 2011). In addition, the metropolitan area of São Paulo city constitutes the most industrialized center of Latin America (Saldiva et al., 1994). In this context, it becomes interesting to compare the organochlorine compound profiles between franciscana dolphins from SP state and air samples from São Paulo City (de Assunção et al., 2005). Considering the PCDF profiles specifically (Fig. 2), for all individuals from SP state, with the exception of BP136, a higher contribution of PeCDF to ¿PCDF in dolphins than in air could be observed. The contribution of PeCDF in dolphin liver samples (excluding BP136 from the analysis) varied from 25.3 to $65.5 \%$ ( $50.8 \pm 11.7$, Mean \pm SD), while in air samples from São Paulo City (de Assunção et al., 2005) a percentage of 12.5 could be observed. A possible explanation for this lies in the selective biomagnification of 2,3,4,7,8-PeCDF reported in literature (Rolff et al., 1993).

For investigating possible gender-related differences on DRC bioaccumulation by franciscana dolphins from SP state, comparisons between sexes were performed regarding $\Sigma$ PCDD, $\Sigma$ PCDF, $\Sigma T E Q-P C D D$,

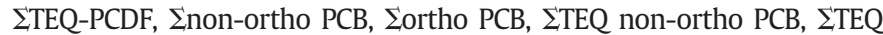
ortho PCB, $\mathrm{EDL}-\mathrm{PCB}, \mathrm{\Sigma TEQ}-\mathrm{DRCS}$, as well as the percent contribution

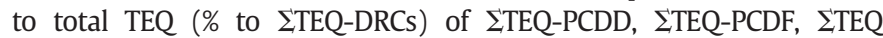
non-ortho PCB and $\Sigma$ TEQ ortho PCB. No significant differences were observed.

Table 1

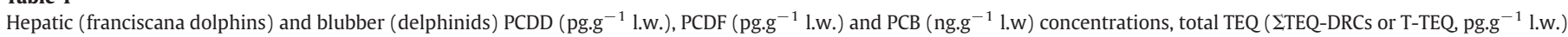
and percentages to T-TEQ (Mean (Median) \pm SD; $[n]$ Min-Max) of cetaceans from Brazil.

\begin{tabular}{|c|c|c|c|c|c|c|c|}
\hline & \multicolumn{2}{|l|}{ Franciscana dolphin } & \multicolumn{2}{|l|}{ Guiana dolphin } & \multicolumn{2}{|c|}{ RT dolphin } & \multirow{2}{*}{$\frac{\text { FK whale }}{\text { Female }}$} \\
\hline & Males & Females & Males & Females & Male & Females & \\
\hline \multirow{4}{*}{$\begin{array}{l}\text { ¿PCDD/DFs } \\
\text { pg/g lipids } \\
\text { ¿PCDD/DFs \% to T-TEQ } \\
\text { percentage }\end{array}$} & $349(141) \pm 433$ & $448(492) \pm 173$ & $52.2(31.6) \pm 35.8$ & $27.3(17.5) \pm 29.3$ & 109 & & 136 \\
\hline & [13] 77.4-1554 & [5] 162-629 & [7] 26.7-123 & [4] 5.13-69.2 & [1] & [2] 17.4-2060 & [1] \\
\hline & $8.89(8.79) \pm 2.92$ & $12.3(11.4) \pm 2.76$ & $0.65(0.48) \pm 0.41$ & $0.20(0.17) \pm 0.13$ & 1.61 & & 0.98 \\
\hline & [11] 4.40-13.5 & [5] 9.76-16.6 & [7] $0.17-1.16$ & [4] $0.09-0.38$ & [1] & [2] 4.82-13.9 & {$[1]$} \\
\hline \multirow{2}{*}{$\begin{array}{l}\text { Enon-ortho PCBs } \\
\text { ng/g lipids }\end{array}$} & $2.79(1.81) \pm 2.43$ & $4.22(2.61) \pm 4.45$ & $5.49(3.87) \pm 3.81$ & $8.30(1.78) \pm 13.2$ & 13.0 & & 10.3 \\
\hline & [13] $0.21-8.17$ & [6] $1.40-13.1$ & [7] $2.35-13.1$ & [4] 1.49-28.1 & [1] & [2] 0.76-5.19 & {$[1]$} \\
\hline \multirow{2}{*}{$\begin{array}{l}\text { Enon-ortho PCBs to T-TEQ } \\
\text { percentage }\end{array}$} & $81.6(85.0) \pm 13.7$ & $82.9(83.4) \pm 2.24$ & $35.6(34.0) \pm 9.36$ & $28.9(24.8) \pm 12.0$ & 41.6 & & 44.1 \\
\hline & [11] 43.3-91.3 & [5] 79.8-85.0 & [7] 24.9-49.4 & [4] 19.6-46.4 & [1] & [2] 13.6-69.4 & {$[1]$} \\
\hline \multirow{2}{*}{$\begin{array}{l}\text { ¿ortho PCBs } \\
\text { ng/g lipids }\end{array}$} & $429(170) \pm 828$ & $139(87.0) \pm 124$ & $13,080(13,060) \pm 2810$ & $14,396(11,116) \pm 11,643$ & 11,054 & & 16,179 \\
\hline & [12] 35.0-3000 & [6] 61.5-385 & [7] 7551-15,804 & [4] 4606-30,748 & [1] & [2] 355-19,844 & [1] \\
\hline \multirow{2}{*}{$\begin{array}{l}\text { Eortho PCBs to T-TEQ } \\
\text { percentage }\end{array}$} & $9.54(4.2) \pm 12.1$ & $4.81(4.58) \pm 1.51$ & $63.7(65.1) \pm 9.57$ & $70.9(75.0) \pm 12.0$ & 56.8 & & 54.9 \\
\hline & [11] 1.80-43.2 & [5] 3.32-7.06 & [7] 49.5-75.0 & [4] 53.5-80.4 & [1] & [2] $25.8-72.5$ & {$[1]$} \\
\hline \multirow{2}{*}{$\begin{array}{l}\text { ¿TEQ-DRCs (T-TEQ) } \\
\text { pg/g lipids }\end{array}$} & $103(67.2) \pm 76.4$ & $86.5(85.0) \pm 49.1$ & $622(568) \pm 150$ & $690(423) \pm 706$ & 583 & & 885 \\
\hline & [11] 38.9-276 & [5] 33.7-164 & [7] 458-886 & [4] 187-1725 & [1] & [2] 41.3-822 & {$[1]$} \\
\hline \multirow{2}{*}{$\begin{array}{l}\text { ¿PCBs (ind. + DL PCBs) } \\
\text { ng/g lipids }\end{array}$} & Not determined & Not determined & $100,290(78,365) \pm 44,751$ & $107,865(58,695) \pm 115,796$ & 74,705 & & 122,004 \\
\hline & & & [7] $56,096-160,355$ & [4] 34,662-279,407 & {$[1]$} & [2] 2510-167,079 & {$[1]$} \\
\hline
\end{tabular}


A

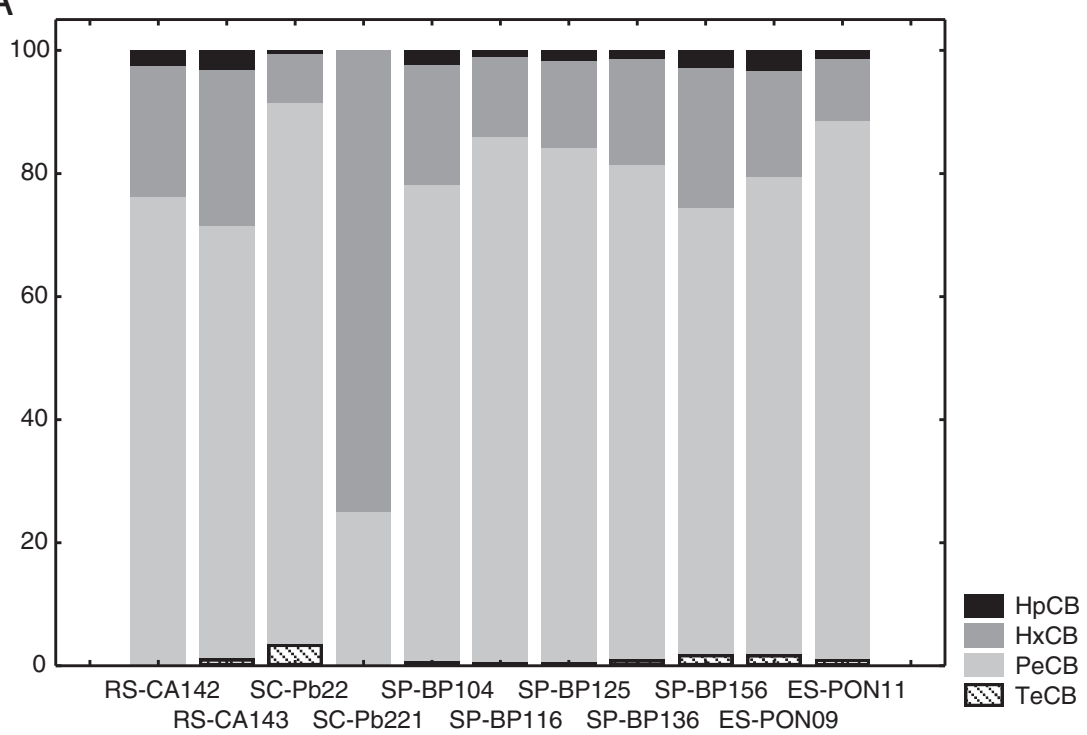

\section{B}
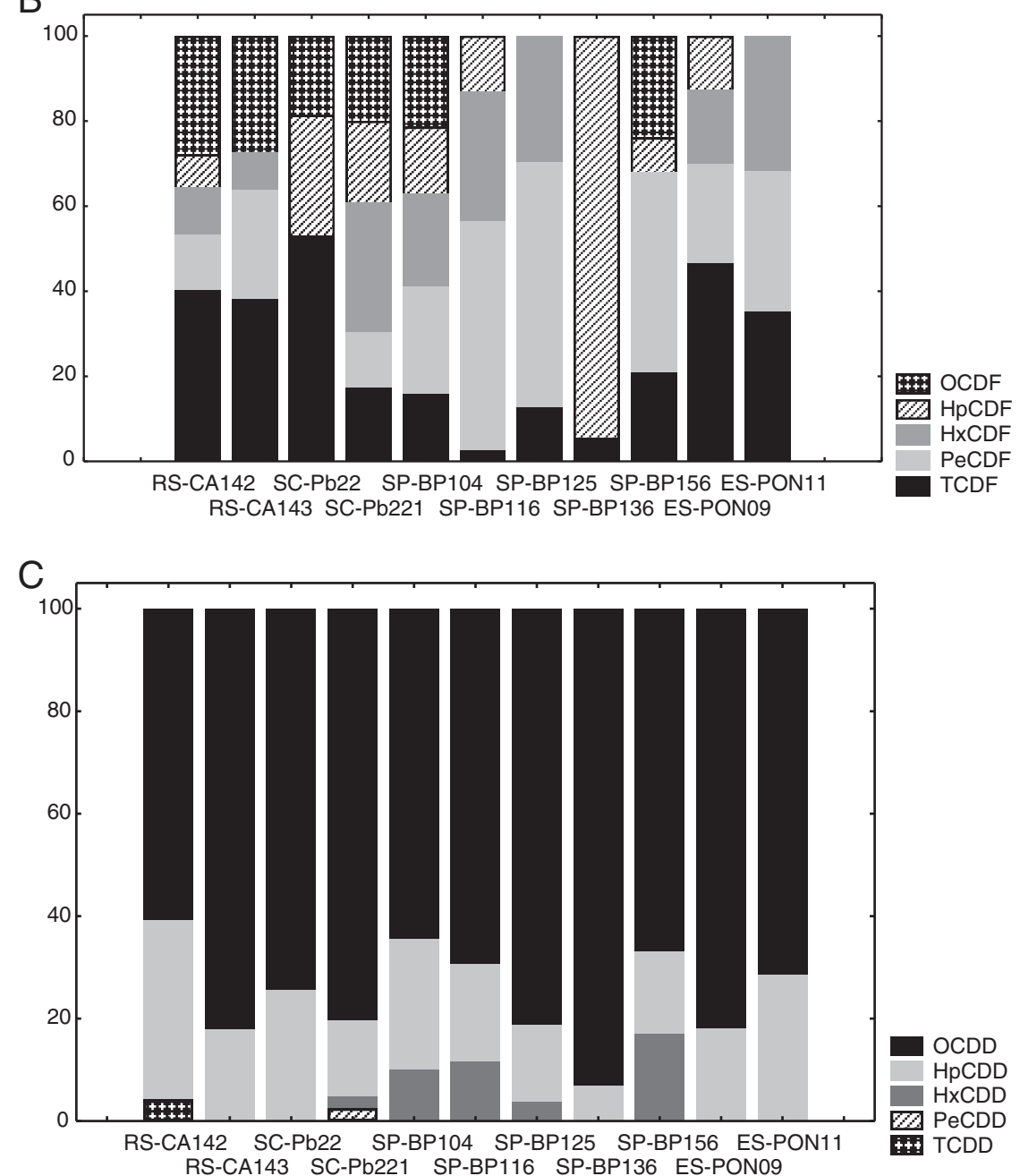

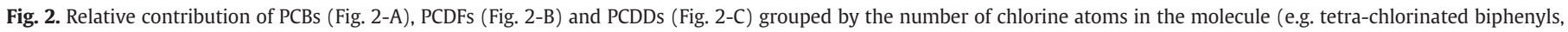

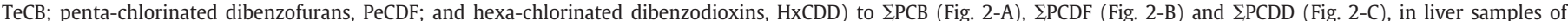

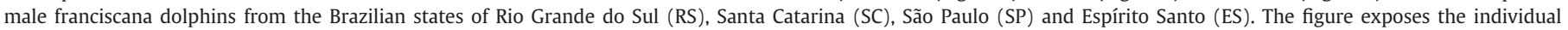
codes of each dolphin (e.g. CA142, CA143, Pb22 and etc.), which are preceded by the identification of the Brazilian state (RS, SC, SP, ES). 
DRC levels in male mammals generally increase with age (O'Shea and Tanabe, 2003); however, a different accumulation pattern is commonly observed for females. This difference is a consequence of the elimination of pollutants through placental and lactational transfer to offspring. In general, concentrations of organohalogen compounds also increase through life in females, but this occurs up to the start of the reproduction, after which the levels reach a plateau or even decrease with age (Dorneles et al., 2010; O'Shea and Tanabe, 2003; Thron et al., 2004). Considering that no significant sex-related differences were observed, as well as that reproduction had not started for immature females, groups constituted of all individuals and composed of males and immature females were also used in statistical treatment scenarios.

For investigating possible correlations between DRC concentrations or TEQ values and total length of franciscana dolphins from SP state, tests were performed in three different scenarios, i.e., regarding only males, males and immature females and all individuals. The pollutantrelated variables investigated were $\Sigma$ PCDD, $\Sigma$ PCDF, $\Sigma T E Q-P C D D$,

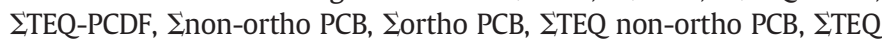
ortho PCB, $\Sigma$ DL-PCB, as well as $\Sigma$ TEQ-DRCs. No significant correlation was found for DRC concentrations; however, correlations were observed for TEQ values. Significant negative correlations were found between total length and three TEQ-related variables, i.e., $\Sigma T E Q-D R C$, ¿TEQ-PCDF and $\Sigma$ TEQ non-ortho PCB, in three different scenarios: considering all individuals (males and females) $(p=0.025$, Rs $=-0.69$; $\mathrm{p}=0.005$, Rs $=-0.81$; and $\mathrm{p}=0.019$, Rs $=-0.69$; for ¿TEQDRCs, $\Sigma$ TEQ-PCDF and $\Sigma$ TEQ non-ortho PCB, respectively); considering the group formed by males and immature females $(p=0.01$, Rs $=-0.83$; for $\Sigma$ TEQ-DRCs and $\Sigma$ TEQ-PCDF; as well as $p=0.005$, Rs $=-0.83$, for $\Sigma$ TEQ non-ortho $\mathrm{PCB}$ ); and considering only males $(\mathrm{p}=0.014, \mathrm{Rs}=-0.95 ; \mathrm{p}=0.015$, Rs $=-0.95 ;$ and $\mathrm{p}=0.011$, Rs $=-0.96$; for $\Sigma$ TEQ-DRCs, 2 TEQ-PCDF and $\Sigma$ TEQ non-ortho PCB, respectively).

As cited above, TEQ values result from the concentrations of the different DRCs as well as from the ability of each compound to induce the Ah-receptor mediated response. Therefore, the fact that correlations with total length were found for TEQ values rather than for concentrations, associated with the fact that they constituted negative correlations, suggests these findings result from chemically-induced developmental disruption. As mentioned, inhibition of growth and development is among the effects attributed to exposure to DRCs (Sanderson and Van Den Berg, 1999). However, an increasing efficiency of the detoxifying activity with the growth of the animal may be a plausible explanation as well (Reijnders, 2003). The concentration ratios between PCB-77 and PCB-169, as well as between PCB-126 and PCB-169, have been used for evaluating enzyme induction and detoxifying activity (Corsolini et al., 2000; Storelli and Marcotrigiano, 2003). Such use is based on the fact that PCB-169 is the most stable coplanar congener (Corsolini et al., 2000). The PCB77/PCB169 and the PCB126/PCB169 concentration ratios of the franciscana dolphins from the present study averaged 29.1 and 7.4, respectively. Therefore, possible correlations between these ratios and total length values of franciscana dolphins from SP were investigated in the same three scenarios mentioned above. A significant negative correlation was found between total length and PCB126/PCB169 concentration ratio for the group formed by males and immature females ( $p=0.036$, Rs $=0.7$ ). The same correlation was not found for the other groups (only males and all individuals) possibly due to the small sample size of the male group, as well as due to the increased number of females in the group composed by all franciscanas. As cited, there are gender-related differences in the metabolizing rates for xenobiotics (Hall, 2002). Nevertheless, this finding reinforces the hypothesis of increasing efficiency of the detoxifying activity with the growth of the animal.

The DRC levels verified in the present study constitute a matter of concern for the conservation of the species. The hepatic PCDD and
PCDF concentrations of franciscana dolphins are high when compared to cetaceans from different regions of the globe (Table 2). In addition, three franciscana dolphins (two males from SP and SC, and 1 female from SP) exhibited LTEQ concentrations within the range of threshold levels for TEQs in livers of aquatic mammals that are capable of eliciting physiological effects (160 to 1400 pg.g ${ }^{-1}$, l.w.) (Kannan et al., 2000). Contamination with pollutants that have been shown to be risk factors for cancer, immune deficiency and reproductive abnormalities (Schecter et al., 2006) constitutes a matter of concern for all species. However, this is especially important for species facing population decreases due to other man-made causes, which enhances the apprehension over this dolphin, as franciscana is the cetacean species most impacted by fisheries in the southwestern Atlantic (Secchi et al., 2003).

\subsection{Guiana dolphins}

Dioxin-like PCBs accounted for over 98.8\% of the total TEQ for all Guiana dolphins from RJ. For this cetacean population, mono-ortho PCBs constituted the group of highest contribution, which varied from 49 to $80 \%$ to the total TEQ. PCB- 118 was the compound of greatest importance among mono-ortho PCB congeners, with an average contribution of $34 \%$ to the total TEQ. This penta-PCB was also the compound with the highest concentrations in the adipose tissue, which varied from 2.81 to $11.5 \mu \mathrm{g} / \mathrm{g}$ (l.w.). PCDDs and PCDFs accounted for less than $1.2 \%$ of the total TEQ in all Guiana dolphins. The predominant PCDD/F congeners found in blubber of Guiana dolphins were OctaCDD (mean \pm SD; $19.4 \pm 29.0 \mathrm{pg} / \mathrm{g}$ lipids) and $1,2,3,4,7,8$-HexaCDF $(6.7 \pm 5.4 \mathrm{pg} / \mathrm{g}$ lipids $)$. Regarding the TEQ values (TEQ pg/g l.w.), 1,2,3,7,8-PentaCDD provided the highest contribution among PCDD/Fs when the average of all Guiana dolphins was considered. However, this penta-chlorinated dibenzo-p-dioxin was not the PCDD/F of greatest contribution to total TEQ for six individuals (two males and the four females).

For investigating possible correlations between DRC concentrations or TEQ values and total length of Guiana dolphins from RJ, tests were performed in two different scenarios, i.e., regarding only males and all individuals. The pollutant-related variables investigated were $\Sigma$ PCDD, $\Sigma$ PCDF, $\Sigma T E Q-P C D D, \Sigma T E Q-P C D F$, ¿non-ortho PCB,

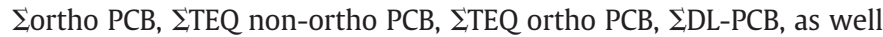
as $\Sigma T E Q$ DL-PCB. No significant correlations were found for DRC concentrations or TEQ values.

For investigating possible gender-related differences on DRC bioaccumulation by Guiana dolphins from RJ, comparisons between sexes were performed regarding $\Sigma$ PCDD, $\Sigma$ PCDF, $\Sigma T E Q-P C D D$,

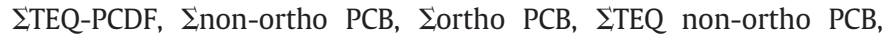

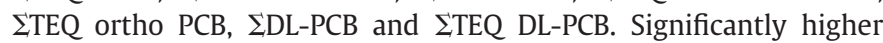
¿TEQ-PCDD levels were verified in males than in females ( $p=$ 0.02 ). Higher persistent bioaccumulative toxicant concentrations in male than in female mammals have been legitimately attributed to the mother-to-calf transfer (O'Shea and Tanabe, 2003). However, the fact that significant differences between sexes were found for TEQ values rather than for concentrations suggests gender-related peculiarities in DRC metabolizing capabilities play an important role in this process. As mentioned above, males and females metabolize DRCs at different rates (Hall, 2002).

\subsection{Rough-toothed dolphins}

On average, dioxin-like PCBs accounted for 93\% of the total TEQ for rough-toothed dolphins from RJ. For this species, the contribution of mono-ortho PCBs to the total TEQ varied from 26 to $72 \%$, and the contribution of non-ortho PCBs was between 14 and 69\%. PCB-118 and $\mathrm{PCB}-126$ were the compounds of highest contribution among mono-ortho and non-ortho coplanar PCB congeners, with contribution percentages to the total TEQ that varied from 13 to $43 \%$ as well 
Table 2

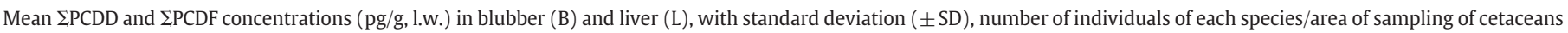
from all over the world.

\begin{tabular}{|c|c|c|c|c|c|c|c|}
\hline Species-common name & Area & $\Sigma$ PCDD mean \pm S.D. & $\Sigma$ PCDF mean \pm S.D. & Sex & Tissue & $\mathrm{n}$ & Ref. \\
\hline Finless porpoise & Japan & 60.9 & 6.0 & N.S. & B & 1 & Tanabe et al. (1989) \\
\hline Killer whale & Japan & N.D. & 345 & M & B & 1 & Ono et al. (1987) \\
\hline Killer whale & Japan & N.D. & $436.8-551.7$ & $\mathrm{~F}$ & B & 2 & Ono et al. (1987) \\
\hline Hector's dolphin & N. Zealand & $38.7 \pm 8.1$ & $41.6 \pm 11.1$ & M & B & 4 & Buckland et al. (1990) \\
\hline Hector's dolphin & N. Zealand & $12.5-37.8$ & $13.6-36.8$ & $\mathrm{~F}$ & B & 2 & Buckland et al. (1990) \\
\hline Killer whale & N. America & N.D. -26.4 & $25.3-42.9$ & N.S. & B & 2 & Jarman et al. (1996) \\
\hline Killer whale & N. America & N.D. -16.5 & $6.6-14.3$ & $\mathrm{M}$ & B & 2 & Jarman et al. (1996) \\
\hline False killer whale & N. America & $4.5-41.9$ & $2.3-117$ & M & B & 2 & Jarman et al. (1996) \\
\hline Dall's porpoise & N. America & $17.4-60.2$ & $50.0-125$ & M & B & 2 & Jarman et al. (1996) \\
\hline Dall's porpoise & N. America & 43.9 & 35.7 & $\mathrm{~F}$ & B & 1 & Jarman et al. (1996) \\
\hline Harbor porpoise & N. America & $84.8 \pm 112$ & $13.1 \pm 14.4$ & M & B & 4 & Jarman et al. (1996) \\
\hline Harbor porpoise & N. America & $103-182$ & $41.3-77.2$ & $\mathrm{~F}$ & B & 2 & Jarman et al. (1996) \\
\hline Risso's dolphin & Italy & $48.9-424$ & $59.2-331$ & M & $\mathrm{L}$ & 2 & Jimenez et al. (2000) \\
\hline Risso's dolphin & Italy & 208 & 706 & $\mathrm{~F}$ & $\mathrm{~L}$ & 1 & Jimenez et al. (2000) \\
\hline Bottlenose dolphin & Italy & $72.3 \pm 46.0$ & $75.3 \pm 44.6$ & M & $\mathrm{L}$ & 4 & Jimenez et al. (2000) \\
\hline Bottlenose dolphin & Italy & 19.2 & 22.9 & $\mathrm{~F}$ & $\mathrm{~L}$ & 1 & Jimenez et al. (2000) \\
\hline Striped dolphin & Italy & $271 \pm 148$ & $92.3 \pm 70.6$ & M & $\mathrm{L}$ & 3 & Jimenez et al. (2000) \\
\hline Striped dolphin & Italy & $186-403$ & $103-162$ & $\mathrm{~F}$ & $\mathrm{~L}$ & 2 & Jimenez et al. (2000) \\
\hline Pilot whale & Italy & 183 & 196 & M & $\mathrm{L}$ & 1 & Jimenez et al. (2000) \\
\hline Harbor porpoise & North Sea & 122 & 12.9 & $\mathrm{~F}$ & B & 1 & Beck et al. (1990) \\
\hline Franciscana dolphin & S-SE Brazil & $236 \pm 323$ & $113 \pm 113$ & M & $\mathrm{L}$ & 13 & PS \\
\hline Franciscana dolphin & SP, Brazil & $348 \pm 163$ & $100 \pm 53.8$ & $\mathrm{~F}$ & $\mathrm{~L}$ & 5 & PS \\
\hline Guiana dolphin & RJ, Brazil & $33.1 \pm 39.0$ & $19.0 \pm 11.3$ & $\mathrm{M}$ & B & 7 & PS \\
\hline Guiana dolphin & RJ, Brazil & $14.2 \pm 16.0$ & $13.1 \pm 13.5$ & $\mathrm{~F}$ & B & 4 & PS \\
\hline Rough-toothed dolphin & RJ, Brazil & 27.2 & 82.0 & M & B & 1 & PS \\
\hline Rough-toothed dolphin & RJ, Brazil & $9.99-747$ & $7.42-1313$ & $\mathrm{~F}$ & B & 2 & PS \\
\hline False killer whale & RJ, Brazil & 24.2 & 112 & $\mathrm{~F}$ & B & 1 & PS \\
\hline
\end{tabular}

PS, present study.

as from 2.3 to $59 \%$. PCB-118 was the compound of highest concentration, which varied from 174 to $11,822 \mathrm{ng} / \mathrm{g}$ (l.w.). Concentrations of PCB-126 varied from 189 to 1940 pg/g lipids. The summed contribution of PCDDs and PCDFs to the total TEQ in rough-toothed dolphins varied from 1.6 to $13.9 \%$. A different pattern was found in Guiana dolphins, for which the contribution of these compound classes was very low. An extremely wide concentration range was observed for the predominant PCDD/F congeners found in blubber of rough-toothed dolphins, since OctaCDD and 1,2,3,4,7,8-HexaCDF levels varied from 6.5 to 713 , as well as from 0.4 to $1026 \mathrm{pg} / \mathrm{g}$ lipids. This organochlorine compound (OC) accumulation pattern, in which extremely high concentrations are found in only a few individuals, has been reported for marine mammals (Hall, 2002). Actually, extremely wide concentration ranges could be found for organohalogen compounds in marine mammals (Dietz et al., 2004; Hall, 2002; Sonne et al., 2008, 2004, 2006b, 2005, 2006c), even reaching a 70-fold variation (Sonne, 2010).

In fact, the $\Sigma$ PCDD (747 pg/g lipids) and $\Sigma$ PCDF (1313 pg/g lipids) concentrations found in blubber of a female rough-toothed dolphin are among the highest ever reported for marine mammals (Table 2). Finding high concentrations of persistent accumulative toxicants in this dolphin population is not surprising. Rough-toothed dolphins from RJ feed on top-predator fish (Bisi et al., 2012; Melo et al., 2010), thus they are more likely to take in high amounts of contaminants that have accumulated in the bodies of the prey.

\subsection{False killer whales}

Concentrations and percent contribution of PCB-118, PCB-126, OctaCDD and 1,2,3,4,7,8-HexaCDF lie within the range mentioned for rough-toothed dolphins, with the exception of the PCB-126 concentration, which was higher for the false killer whale $(2179 \mathrm{pg} / \mathrm{g}$ lipids). It is important to note that, as there was only one individual, the pollutant levels and profiles may not be representative of the population. Despite this, the $\Sigma$ PCDD and $\Sigma$ PCDF concentrations found in our study compare favorably with data for false killer whales from North America (Jarman et al., 1996) (Table 2).

\subsection{A serious $P C B$ problem}

Comparing DRC concentrations in franciscana dolphins from SP with levels of the same compounds in Guiana dolphins from $\mathrm{RJ}$ is a difficult task, since contaminant determination was performed in liver and blubber, respectively. Evaluating the body distribution of lipophilic organohalogen compounds in cetaceans, Watanabe et al. (1999) and Ramu et al. (2005) observed that, in general, the highest levels are found in blubber, even considering lipid normalized concentrations. However, different body distribution patterns are observed for compounds of the same chemical class (Kunisue et al., 2008). An investigation that dealt with DRC concentrations in raccoon dogs from Japan showed that the HxCB-157 ratio in liver/adipose tissue presented values close to 1.0 (Kunisue et al., 2006). To the authors' knowledge, this approach has not been applied to cetaceans yet. Although species-specific differences in toxicokinetics of DRCs may exist, the latter cited investigation turned HxCB-157 into the most suitable compound for comparison between liver and adipose tissue concentrations. Therefore, statistical comparison between the HxCB-157 concentrations of franciscana dolphins and Guiana dolphins was performed, limiting it to male dolphins from SP and RJ, respectively. The HxCB-157 concentrations found in Guiana dolphins were significantly higher than those found in franciscana dolphins $(p=0.003)$. Since both data sets presented normal distribution, the mean values were used as a reference and it could be observed that HxCB-157 levels of Guiana dolphins were supposedly 75 times those of franciscana dolphins. Even considering two dolphin species, this should be done with caution due to possible species-specific differences in metabolism. However, it was the most appropriate among the available tools for comparing the exposure to PCBs between both odontocete species/populations. Nonetheless, this finding suggests that Guiana dolphins from RJ are more exposed to PCBs than franciscana dolphins from SP.

PCB levels found in Guiana dolphins in the present study are among the highest ever reported for cetaceans. For instance, these concentrations were in the range reported by Kuehl et al. (1991) and Berggren et al. (1999) in blubber samples from bottlenose, 
common and white-sided dolphins from the U.S. Atlantic Coast (Kuehl et al., 1991), as well as from male harbor porpoises from the Baltic Sea, the Kattegat-Skagerrak Seas and the West Coast of Norway (Berggren et al., 1999). In the study performed by Kuehl et al. (1991), the total PCB concentrations varied from 17.4 to $195 \mu \mathrm{g} / \mathrm{g}$ lipid, and in the investigation conducted by Berggren et al. (1999), the levels varied between 2.2 and $78 \mu \mathrm{g} / \mathrm{g}$ lipid (sum of CB52, CB101, CB118, CB138, CB153 and CB180). The concentration range reported by Kuehl et al. (1991) comprises the sum of one hundred PCB congeners, much more than the 18 PCB congeners determined in the present study. In Kuehl et al. (1991) and Berggren et al. (1999), cetaceans were collected from 1978 to 1990. During the 1970s and 1980s, the manufacturing of PCBs was terminated in most industrialized nations. This implies further that the animals analyzed by Kuehl et al. (1991) and Berggren et al. (1999) lived not only in a highly polluted area but also in a period of elevated environmental contamination by PCBs. The sample set analyzed by Kuehl et al. (1991) included bottlenose dolphins obtained after an unusual mortality event. Although the impact of these immunosuppressive compounds (Sonne et al., 2006a) is not fully known, their role as causative agents in that mass mortality was considered by the authors (Kuehl et al., 1991), which emphasizes the toxicological importance of the concentrations found in Guiana dolphins from RJ. Among cetaceans species, the highest concentrations of biomagnifying pollutants are usually found in killer whales, due to their predation on organisms that occupy high trophic positions, such as sharks, seals and other cetaceans (O'Shea and Tanabe, 2003). Therefore, the magnitude of the delphinid exposure to PCBs in RJ waters can be exemplified with the fact that concentrations found in these dolphins are comparable to the levels verified in killer whales from Alaska (Ylitalo et al., 2001).

Interestingly, 10 out of the 11 Guiana dolphins analyzed in the present study were found in Guanabara Bay, which may explain the extremely high PCB concentrations found. Guanabara Bay is the most anthropogenically disturbed area along the Brazilian coast (Dorneles et al., 2008b). The estuary is bordered by more than 14,000 industries and four cities (Wasserman et al., 2006) with a population of more than 10 million people (Jablonski et al., 2006; Kjerfve et al., 1997). Despite the anthropogenic pressure, the small Guiana dolphin population exhibits habitat fidelity to Guanabara Bay, since the same individuals are found year-round in this site (Azevedo et al., 2004), where feeding-related activities predominate (Azevedo et al., 2007). In addition to the expected contamination by PCBs from a highly urbanized and industrialized area, some activities in Rio de Janeiro amplify the apprehension. Eleven thousand liters of Aroclor were stolen from an abandoned building in Rio de Janeiro City in September 2005 (ALERJ, 2005). This raises suspicion on the existence of an illegal market and usage of PCBs in Brazil, which is a serious reason for concern in terms of environmental pollution.

The Brazilian economic growth and the consequent use and degradation of the coastal zone are a threat to the conservation of coastal cetaceans. A large set of construction works is planned for the establishment of harbors, shipyards and industries on Brazilian coastal bays and their drainage basins. Many of these estuaries have been suffering from a large series of different types of pressure, as well as they have been going through broad dredging and even submarine demolishing. Some Brazilian bays seem to be on the same degradation path once followed by Guanabara Bay, which harbors a residual Guiana dolphin population assessed to be around 40 individuals only (Azevedo et al., submitted for publication). Environmental contamination by DRCs constitutes one additional obstacle for these marine mammals to reach their natural longevity and reproduce at a physiologically normal rate. The concerns generated by the DRC contamination are amplified when it is taken into account that these cetaceans are exposed to other persistent bioaccumulative toxicants (PBTs) that have been shown to be endocrine disrupters, tumor promoters and immunosuppressors as well (Schecter et al., 2006;
Simonyte et al., 2006; Sonne et al., 2006a; Whalen et al., 1999). The high exposure of cetaceans from Brazil to cadmium (Dorneles et al., 2007a, 2007b), mercury (Lailson-Brito et al., 2012a), organochlorine pesticides (Lailson-Brito et al., 2011, 2010, 2012b), as well as to organotin (Dorneles et al., 2008b), perfluoroalkyl (Dorneles et al., 2008a) and organobrominated (Alonso et al., 2012; Dorneles et al., 2010) compounds has already been reported. Therefore, the possibility of synergistic effects among these PBTs should not be ruled out.

The data generated by the present study raises apprehension on the possibility of human health problem due to consumption of fish from Brazilian estuaries. This apprehension is augmented when it is considered that many fish species are consumed by humans in Rio de Janeiro at the size preyed on by Guiana dolphins from Guanabara Bay (Melo et al., submitted for publication). Therefore, risk assessment studies on human exposure to PCBs through consumption of fish from Guanabara Bay are of fundamental importance.

\section{Conflict of interest}

The authors state that there is no conflict of interest.

\section{Acknowledgments}

This work was supported by the Ministry of Education of BrazilCAPES ("Ciências do Mar"-Proc. 23038.051661/2009-18, as well as fellowship to M.B. Alonso, "Sandwich Programme"-PDEE), by the Brazilian Research Council-CNPq and by Rio de Janeiro State Government Research Agency-FAPERJ ("Pensa Rio" Program). This study was also supported by a scientific cooperation established between CNPq and F.R.S.-FNRS (Proc. 490471/2010-2 CNPq). The Yaqu Pacha Foundation is acknowledged for its financial support to research projects that allowed cetacean carcass recovery. Dr. Lailson-Brito is a researcher of "Prociência" Program-FAPERJ/UERJ. Dr. Azevedo has a research grant from CNPq (grant No. 304826/2008-1). Since Dr. Torres is partially funded by Grant 1D43TW00640 from the Fogarty International Center of the National Institute of Health, this institution is also acknowledged. Dr. Torres is also a Research Fellow of CNPq and FAPERJ. Krishna Das is a F.R.S.-FNRS research associate.

\section{References}

Alcock RE, Gemmill R, Jones KC. Improvements to the UK PCDD/F and PCB atmospheric emission inventory following an emissions measurement programme. Chemosphere 1999;38:759-70.

ALERJ. Roubo de ascarel. 100. Jornal da Assembléia Legislativa do Estado do Rio de Janeiro; 20055.

Alonso MB, Eljarrat E, Gorga M, Secchi ER, Bassoi M, Barbosa L, et al. Natural and anthropogenically-produced brominated compounds in endemic dolphins from Western South Atlantic: another risk to a vulnerable species. Environ Pollut 2012;170:152-60.

Azevedo e Silva CE, Torres JPM, Malm O. Toxicologia das Bifenilas Policloradas. Oecologia Bras 2007;11:179-87.

Azevedo AF, Lailson-Brito J, Cunha HA, van Sluys M. A note on site fidelity of marine tucuxis (Sotalia fluviatilis) in Guanabara Bay, southeastern Brazil. J Cetac Res Manage 2004;6:265-8

Azevedo AF, Oliveira AM, Viana SC, van Sluys M. Habitat use by marine tucuxis (Sotalia guianensis) (Cetacea: Delphinidae) in Guanabara Bay, south-eastern Brazil. J Mar Biol Assoc UK 2007; 87:201-5.

Azevedo AF, van Sluys M, Carvalho RR, Dorneles PR, Lailson-Brito J. Trends in Sotalia guianensis (Cetacea: Delphinidae) abundance in Guanabara Bay, Southeastern Brazil. J Mar Biol Assoc UK 2013. [submitted for publication].

Baird RW. False killer whale: Pseudorca crassidens. In: Perrin WF, Würsig B, Thewissen JGM, editors. Encyclopedia of Marine Mammals. 2nd ed. San Diego, California: Academic Press; 2009. p. 405-6.

Baird RW, Gorgone AM, McSweeney DJ, Webster DL, Salden DR, Deakos MH, et al. False killer whales (Pseudorca crassidens) around the main Hawaiian Islands: long-term site fidelity, inter-island movements, and association patterns. Mar Mamm Sci 2008;24:591-612

Ballschmiter $\mathrm{K}$, Wittlinger R. Interhemisphere exchange of hexachlorocyclohexanes, hexachlorobenzene, polychlorobiphenyls, and 1,1,1-trichloro-2,2-bis(p-chlorophenyl) ethane in the lower troposphere. Environ Sci Technol 1991;25:1103-11.

Beck H, Breuer EM, Droß A, Mathar W. Residues of PCDDs, PCDFs, PCBs and other organochlorine compounds in harbor seals and harbor porpoise. Chemosphere 1990;20: 1027-34. 
Berggren P, Ishaq R, Zebühr Y, NÄf C, Bandh C, Broman D. Patterns and levels of organochlorines (DDTs, PCBs, non-ortho PCBs and PCDD/Fs) in male harbour porpoises (Phocoena phocoena) from the Baltic Sea, the Kattegat-Skagerrak Seas and the West Coast of Norway. Mar Pollut Bull 1999;38:1070-84.

Bisi TL. Relações tróficas e biomagnificação do mercúrio nas cadeias alimentares marinhas da costa do Estado do Rio de Janeiro. [PhD.]Rio de Janeiro: Federal University of Rio de Janeiro; 2011255.

Bisi TL, Lepoint G, Azevedo ADF, Dorneles PR, Flach L, Das K, et al. Trophic relationships and mercury biomagnification in Brazilian tropical coastal food webs. Ecol Indic 2012;18:291-302.

Bjørge A. How persistent are marine mammal habitats in an ocean of variability? Habita use, home range and site fidelity in marine mammals. In: Evans PGH, Raga JA, editors. Marine Mammals: Biology and Conservation. New York: Kluwer Academic/Plenum Publishers; 2001. p. 63-91.

Bopp RF, Gross ML, Tong H, Simpson HJ, Monson SJ, Deck BL, et al. A major incident of dioxin contamination-sediments of New Jersey estuaries. Environ Sci Technol 1991;25:951-6.

Buckland SJ, Hannah DJ, Taucher JA, Slooten E, Dawson S. Polychlorinated dibenzo-para-dioxins and dibenzofurans in New Zealand hectors dolphin. Chemosphere 1990;20:1035-42.

Chaloupka K, Harper N, Krishnan V, Santostefano M, Rodriguez LV, Safe S. Synergistic activity of polynuclear aromatic hydrocarbon mixtures as aryl-hydrocarbon (ah) receptor agonists. Chem Biol Interact 1993;89:141-58.

Cleemann M, Riget F, Paulsen GB, Dietz R. Organochlorines in Greenland glaucous gulls (Larus hyperboreus) and Icelandic gulls (Larus glaucoides). Sci Total Environ 2000;245:117-30.

Corsolini S, Aurigi S, Focardi S. Presence of polychlorobiphenyls (PCBs) and coplanar congeners in the tissues of the Mediterranean loggerhead turtle Caretta caretta. Mar Pollut Bull 2000;40:952-60.

Cunha HA, da Silva VMF, Lailson-Brito J, Santos MCO, Flores PAC, Martin AR, et al. Riverine and marine ecotypes of Sotalia dolphins are different species. Mar Biol 2005;148:449-57

de Assunção JV, Pesquero CR, Bruns RE, Carvalho LRF. Dioxins and furans in the atmosphere of São Paulo City, Brazil. Chemosphere 2005;58:1391-8.

Dietz R, Ansen CT, Have P, Heide-Jørgensen MP. Clue to seal epizootic. Nature 1989;338:627.

Dietz R, Riget F, Hobson KA, Heide-Jørgensen MP, Møller P, Cleemann M, et al. Regiona and inter annual patterns of heavy metals, organochlorines and stable isotopes in narwhals (Monodon monoceros) from West Greenland. Sci Total Environ 2004;331: 83-105.

Dorneles PR, Lailson-Brito J, Santos RA, Costa PAS, Malm O, Azevedo AF, et al. Cephalopods and cetaceans as indicators of offshore bioavailability of cadmium off Central South Brazil Bight. Environ Pollut 2007a;148:352-9.

Dorneles PR, Lailson-Brito J, Secchi ER, Bassoi M, Lozinsky CPC, Torres JPM, et al. Cadmium concentrations in franciscana dolphin (Pontoporia blainvillei) from South Brazilian coast. Braz J Oceanogr 2007b;55:179-86.

Dorneles PR, Lailson-Brito J, Azevedo AF, Meyer J, Vidal LG, Fragoso AB, et al. High accumulation of perfluorooctane sulfonate (PFOS) in marine tucuxi dolphins (Sotalia guianensis) from the Brazilian coast. Environ Sci Technol 2008a;42:5368-73.

Dorneles PR, Lailson-Brito J, Fernandez MAS, Vidal LG, Barbosa LrA, Azevedo AF, et al. Evaluation of cetacean exposure to organotin compounds in Brazilian waters through hepatic total tin concentrations. Environ Pollut 2008b;156:1268-76.

Dorneles PR, Lailson-Brito J, Dirtu AC, Weijs L, Azevedo AF, Torres JPM, et al. Anthropogenic and naturally-produced organobrominated compounds in marine mammals from Brazil. Environ Int 2010:36:60-7.

Eljarrat E, Martinez MÁ, Sanz P, Concejero MÁ, Piña B, Quirós L, et al. Distribution and biological impact of dioxin-like compounds in risk zones along the Ebro River basin (Spain). Chemosphere 2008;71:1156-61.

Flores PAC, Ximinez A. Observations on the rough-toothed dolphin Steno bredanensis off Santa Catarina Island, southern Brazilian coast. Biotemas 1997;10:71-9.

Focant J-F, Eppe G, Pirard C, De Pauw E. Fast clean-up for polychlorinated dibenzop-dioxins, dibenzofurans and coplanar polychlorinated biphenyls analysis of highfat-content biological samples. J Chromatogr A 2001;925:207-21.

Hall AJ. Organohalogenated contaminants in marine mammals. In: Evans PGH, Raga JA, editors. Marine Mammals: Biology and Conservation. New York: Kluwer Academic/ Plenum Publishers; 2002. p. 523-63.

Harper N, Connor K, Safe S. Immunotoxic potencies of polychlorinated biphenyl (pcb), dibenzofuran (pcdf) and dibenzo-p-dioxin (pcdd) congeners in c57bl/6 and dba/2 mice. Toxicology 1993;80:217-27.

Jablonski S, Azevedo AD, Moreira LHA. Fisheries and conflicts in Guanabara Bay, Rio de Janeiro, Brazil. Braz Arch Biol Technol 2006;49:79-91.

Jarman WM, Norstrom RJ, Muir DCG, Rosenberg B, Simon M, Baird RW. Levels of organochlorine compounds, including PCDDS and PCDFS, in the blubber of cetaceans from the west coast of North America. Mar Pollut Bull 1996;32:426-36.

Jefferson TA. Rough-toothed dolphin Steno bredanensis. In: Perrin WF, Würsig B, Thewissen JGM, editors. Encyclopedia of Marine Mammals. San Diego, California: Academic Press; 2009. p. 990-2.

Jimenez B, Gonzalez MJ, Jimenez O, Reich S, Eljarrat E, Rivera J. Evaluation of 2,3,7,8 specific congener and toxic potency of persistent polychlorinated dibenzop-dioxins and polychlorinated dibenzofurans in cetaceans from the Mediterranean Sea, Italy. Environ Sci Technol 2000;34:756-63.

Kannan K, Blankenship AL, Jones PD, Giesy JP. Toxicity reference values for the toxic effects of polychlorinated biphenyls to aquatic mammals. Hum Ecol Risk Assess 2000;6:181-201.

Kjerfve B, Ribeiro CHA, Dias GTM, Filippo AM, Da Silva Quaresma V. Oceanographic characteristics of an impacted coastal bay: Baía de Guanabara, Rio de Janeiro, Brazil. Cont Shelf Res 1997;17:1609-43.
Kuehl DW, Haebler R, Potter C. Chemical residues in dolphins from the U.S. Atlantic coast including Atlantic bottlenose obtained during the 1987/88 mass mortality. Chemosphere 1991;22:1071-84.

Kunisue T, Watanabe MX, Iwata H, Tsubota T, Yamada F, Yasuda M, et al. PCDDs, PCDFs, and coplanar PCBs in wild terrestrial mammals from Japan: congener specific accumulation and hepatic sequestration. Environ Pollut 2006;140:525-35.

Kunisue T, Takayanagi N, Isobe T, Takahashi S, Nakatsu S, Tsubota T, et al. Regional trend and tissue distribution of brominated flame retardants and persistent organochlorines in raccoon dogs (Nyctereutes procyonoides) from Japan. Environ Sci Technol 2008;42:685-91.

Lailson-Brito J, Dorneles PR, Azevedo-Silva CE, Azevedo AF, Vidal LG, Zanelatto RC, et al. High organochlorine accumulation in blubber of Guiana dolphin, Sotalia guianensis, from Brazilian coast and its use to establish geographical differences among populations. Environ Pollut 2010;158:1800-8.

Lailson-Brito J, Dorneles PR, Azevedo-Silva CE, Azevedo AF, Vidal LG, Marigo J, et al. Organochlorine concentrations in franciscana dolphins, Pontoporia blainvillei, from Brazilian waters. Chemosphere 2011;84:882-7.

Lailson-Brito J, Cruz R, Dorneles PR, Andrade L, Azevedo AdF, Fragoso AB, et al. Mercuryselenium relationships in liver of Guiana Dolphin: the possible role of Kupffer cells in the detoxification process by Tiemannite formation. PLoS One 2012a;7.

Lailson-Brito J, Dorneles PR, Azevedo-Silva CE, Bisi TL, Vidal LG, Legat LN, et al. Organochlorine compound accumulation in delphinids from Rio de Janeiro State, southeastern Brazilian coast. Sci Total Environ 2012b;433:123-31.

Lara LL, Artaxo P, Martinelli LA, Camargo PB, Victoria RL, Ferraz ESB. Properties of aerosols from sugar-cane burning emissions in Southeastern Brazil. Atmos Environ 2005;39: 4627-37.

McDonald SJ, Kennicutt MC, Sericano J, Wade TL, Liu H, Safe SH. Correlation between bioassay-derived p4501a1 induction activity and chemical-analysis of clam (laternula elliptica) extracts from McMurdo Sound, Antarctica. Chemosphere 1994;28:2237-48.

Melo CLC, Santos RA, Bassoi M, Araujo AC, Lailson-Brito J, Dorneles PR, et al. Feeding habits of delphinids (Mammalia: Cetacea) from Rio de Janeiro State, Brazil. J Mar Biol Assoc UK 2010;90:1509-15.

Melo CLC, Santos RA, Bassoi M, Araújo AC, Lailson-Brito J, Dorneles PR, et al. Feeding habits of Guiana dolphins (Sotalia guianensis) (Cetacea: Delphinidae) from Guanabara Bay, Rio de Janeiro, Brazil. Estuar Coast Shelf Sci 2013. [submitted for publication]

Miyazaki N, Perrin WF. Rough-toothed dolphin Steno bredanensis (Lesson, 1828). In: Ridgway SH, Harrison R, editors. Handbook of Marine Mammals, 5. San Diego, California: Academic Press; 1994. p. 1-21.

O'Shea TJ, Tanabe S. Persistent ocean contaminants and marine mammals: a retrospective overview. In: Vos JG, Bossart GD, Fournier M, O'Shea TJ, editors. Toxicology of marine mammals. London: Taylor and Francis; 2003. p. 99-134.

Ono M, Kannan N, Wakimoto T, Tatsukawa R. Dibenzofurans: a greater global pollutant than dioxins? Evidence from analyses of open ocean killer whale. Mar Pollut Bull 1987; $18: 640-3$

Penteado JCP, Vaz JM. The legacy of the polychlorinated biphenyls (PCBs). Quim Nova $2001 ; 24: 390-8$

Ramu K, Kajiwara N, Tanabe S, Lam PKS, Jefferson TA. Polybrominated diphenyl ethers (PBDEs) and organochlorines in small cetaceans from Hong Kong waters: levels, profiles and distribution. Mar Pollut Bull 2005;51:669-76.

Reijnders PJH. Reproductive failure in common seals feeding on fish from polluted coastal waters. Nature 1986;324:456-7.

Reijnders PJH. Reproductive and developmental effects of environmental organochlorines on marine mammals. In: Vos JG, Bossart GD, Fournier M, O'Shea TJ, editors. Toxicology of Marine Mammals. London: Taylor and Francis; 2003. p. 55-66.

Rolff C, Broman D, Näf C, Zebühr Y. Potential biomagnification of PCDD/Fs-new possibilities for quantitative assessment using stable isotope trophic position. Chemosphere $1993 ; 27: 461-8$

Rudge CVC, Calderon IMP, Rudge MVC, Volpato G, Silva JLP, Duarte G, et al. Toxic and essential elements in blood from delivering women in selected areas of São Paulo State, Brazil. J Environ Monit 2011;13:563-71.

Saboia J. Desconcentração industrial no Brasil nos anos 90: um enfoque regional. Pesqui Planej Econ 2000;30:69-116.

Saldiva PHN, Lichtenfels AJFC, Paiva PSO, Barone IA, Martins MA, Massad E, et al. Association between air pollution and mortality due to respiratory diseases in children in São Paulo, Brazil: a preliminary report. Environ Res 1994;65:218-25.

Sanderson JT, Van Den Berg M. Toxic equivalency factors (TEFs) and their use in ecological risk assessment: a successful method when used appropriately. Hum Ecol Risk Assess (HERA) 1999;5:43-52

Santilli M, Moutinho P, Schwartzman S, Nepstad D, Curran L, Nobre C. Tropical deforestation and the Kyoto Protocol. Clim Change 2005;71:267-76.

Schecter A, Birnbaum L, Ryan JJ, Constable JD. Dioxins: an overview. Environ Res 2006;101:419-28.

Secchi ER, Danilewicz D, Ott PH. Applying the phylogeographic concept to identify franciscana dolphin stocks: implications to meet management objectives. J Cetac Res Manage 2003;5:61-8.

Simonyte S, Planciuniene R, Cherkashin G. Influence of cadmium and selenite ions on the mice resistance to experimental bacterial infection. Trace Elem Electrolytes 2006;23:277-80

Sonne C. Health effects from long-range transported contaminants in Arctic top predators: an integrated review based on studies of polar bears and relevant model species. Environ Int 2010;36:461-91.

Sonne C, Dietz R, Born EW, Riget FF, Kirkegaard M, Hyldstrup L, et al. Is bone mineral composition disrupted by organochlorines in East Greenland polar bears (Ursus maritimus)? Environ Health Perspect 2004;112:1711-6. 
Sonne C, Dietz R, Leifsson PS, Born EW, Letcher RJ, Kirkegaard M, et al. Do organohalogen contaminants contribute to histopathology in liver from east Greenland polar bears (Ursus maritimus)? Environ Health Perspect 2005;113:1569-74.

Sonne C, Dietz R, Larsen HJS, Loft KE, Kirkegaard M, Letcher RJ, et al. Impairment of cellular immunity in West Greenland sledge dogs (Canis familiaris) dietary exposed to polluted Minke whale (Balaenoptera acutorostrata) blubber. Environ Sci Technol 2006a;40: 2056-62.

Sonne C, Dietz R, Leifsson PS, Born EW, Kirkegaard M, Letcher RJ, et al. Are organohalogen contaminants a cofactor in the development of renal lesions in East Greenland polar bears (Ursus maritimus)? Environ Toxicol Chem 2006b;25:1551-7.

Sonne C, Leifsson PS, Dietz R, Born EW, Letcher RJ, Hyldstrup L, et al. Xenoendocrine pollutants may reduce size of sexual organs in East Greenland polar bears (Ursus maritimus). Environ Sci Technol 2006c;40:5668-74.

Sonne C, Bossi R, Dietz R, Leifsson PS, Rigét FF, Born EW. The potential correlation between perfluorinated acids and liver morphology in East Greenland polar bears (Ursus maritimus). Toxicol Environ Chem 2008;90:275-83.

Storelli MM, Marcotrigiano GO. Levels and congener pattern of polychlorinated biphenyls in the blubber of the Mediterranean bottlenose dolphins Tursiops truncatus. Environ Int 2003;28:559-65.

Tanabe S, Kannan N, Ono M, Tatsukawa R. Toxic threat to marine mammals: increasing toxic potential of non-ortho and mono-ortho coplanar PCBs from land to ocean. Chemosphere 1989;18:485-90.
Thron KU, Bruhn R, McLachlan MS. The influence of age, sex, body-condition, and region on the levels of PBDEs and toxaphene in harbour porpoises from European waters. Fresenius Environ Bull 2004;13:146-55.

van den Berg M, Birnbaum LS, Denison M, de Vito M, Farland W, Feeley M, et al. The 2005 World Health Organization reevaluation of human and mammalian toxic equivalency factors for dioxins and dioxin-like compounds. Toxicol Sci 2006;93: 223-41.

Wasserman JC, Botelho ALM, Crapez MAC, Bispo MGS, Filgueiras CM. Hydrocarbons and bacterial activity in mangrove sediments from Guanabara Bay, Brazil. Geochim Bras 2006;20:14-25

Watanabe M, Tanabe S, Miyazaki N, Petrov EA, Jarman WM. Contamination of tris(4-chlorophenyl) methane and tris(4-chlorophenyl) methanol in marine mammals from Russia and Japan: body distribution, bioaccumulation and contamination status. Mar Pollut Bull 1999;39:393-8.

Whalen MM, Loganathan BG, Kannan K. Immunotoxicity of environmentally relevant concentrations of butyltins on human natural killer cells in vitro. Environ Res 1999;81:108-16.

Ylitalo GM, Matkin CO, Buzitis J, Krahn MM, Jones LL, Rowles T, et al. Influence of life-history parameters on organochlorine concentrations in free-ranging killer whales (Orcinus orca) from Prince William Sound, AK. Sci Total Environ 2001;281: 183-203. 